\title{
MÚSICOS DE LAS COMPAÑÍAS QUE RESIDEN EN ESTA CORTE: MÚSICOS Y EMPRESA TEATRAL EN MADRID EN EL SIGLO DE ORO
}

\author{
MÚSICOS DE LAS COMPAÑÍAS QUE RESIDEN EN ESTA CORTE: \\ MUSICIANS AND THEATRE COMPANIES IN THE GOLDEN AGE \\ IN MADRID
}

\author{
María Asunción Flórez Asensio \\ Consejería de Educación. Comunidad de Madrid
}

\begin{abstract}
Resumen:
La importancia concedida a la música en el teatro hispano impuso la presencia de músicos en las compañías profesionales desde su aparición como tales a mediados del siglo XVI, y muy especialmente en las que actuaban en Madrid, villa y corte, ya que fueron estos músicos los que interpretaron y pusieron en práctica las novedades introducidas por los músicos de cámara al servicio de la Casa Real en el teatro cortesano, verdadero motor del teatro musical hispano, interpretado por los mismos músicos y actores que representaban en los corrales. Sin embargo, el importante papel que jugaron estos músicos ha quedado oscurecido por la fama alcanzada por sus compañeras, las actrices-músicas, pese a que ellos, desde su posición jerárquica intermedia dentro de las compañías, desarrollaron un trabajo esencial para el éxito de las mismas, contribuyendo así de forma decisiva a su supervivencia y viabilidad.
\end{abstract}

\section{Palabras clave:}

Músicos de compañías teatrales de Madrid (siglo XVII); Música en España (siglo XVII); Gaspar Real, Gregorio de la Rosa; Juan de Serqueira; Manuel de Villaflor.

\begin{abstract}
:
The importance of Music in Hispanic theatre was so important that it required the presence of musicians in the professional companies since their appearance around the mid 16th century. This was especially so in the groups that acted in Madrid, city and court, due to the fact that these musicians interpreted and implemented the innovations introduced by the chamber musicians serving the Royal Family (Casa Real ) in the court theatre, the true motor behind the hispanic musical theatre. This was interpreted by the same musicians and actors who presented plays in the popular theatres. However, the important role these musicians played was overshadowed by the actress-musicians with whom they worked. In spite of their intermediate position within the companies, the musicians carried out an essential role in the success of the productions, contributing decisively to their survival and viability.
\end{abstract}


Key Words:

Musicians in the professional companies in Madrid (17th century); Music in Spain (17th century); Gaspar Real, Gregorio de la Rosa; Juan de Serqueira; Manuel de Villaflor.

La importancia concedida a la música en el teatro español de la Edad Moderna impuso la presencia de músicos en las compañías profesionales desde su aparición como tales a mediados del siglo Xvi, cuando las representaciones teatrales se convierten en un hecho cotidiano al generalizarse, entre las diversas capas urbanas, la costumbre de asistir al teatro, lo que permite la profesionalización del hecho teatral.

Basada en los modelos mercantiles de la burguesía, la compañía se configura como una empresa perfectamente organizada que integra a todos aquellos que participan en el hecho teatral (autor ${ }^{1}$, actores y personal auxiliar), estableciendo entre ellos una clara jerarquización en función de sus diferentes oficios, categoría y méritos artísticos ${ }^{2}$, y los músicos formarán parte de la misma desde sus orígenes, aunque inicialmente no siempre se especifique su cualidad de tales. Sin embargo, a medida que avanza el siglo xVII y las exigencias musicales aumentan, se produce una clarificación en sus funciones y una mayor especialización, estableciéndose dos categorías principales: músico principal y arpista. En ocasiones esta plantilla podía verse incrementada con un "segundo músico", pero éste no siempre aparece.

1 Empresario, además de actor, constituye una figura esencial para el desarrollo del teatro comercial al asumir una gran cantidad de responsabilidades artísticas y económicas vitales para la supervivencia de las compañías profesionales, tal y como se pone de manifiesto a finales del siglo XVII cuando, ante la crisis generalizada, se hace muy difícil contar con las compañías adecuadas ya que los posibles autores se retraen por no hallarse "[...] con fuerzas de caudal ni salud para serlo [...]", tal y como declara en 1675 Simón Aguado, célebre gracioso y autor desde 1662. Ver en SHERgold, Norman D. y VAREY, John E.: Los autos sacramentales en Madrid en la época de Calderón. Madrid, Edhigar, 1961, p. 285.

2 Las compañías estaban constituidas por un promedio de veinte personas, entre hombres y mujeres, siendo estas últimas esenciales pese a su inferioridad numérica. Dentro de los oficios "artísticos" el nivel más alto lo ocupaban los actores y actrices que representaban primeros y segundos papeles de dama y galán. Figuras intermedias eran los que representaban papeles de tercer o cuarto galán y dama y los graciosos. Un nivel inferior correspondía a papeles secundarios como quintos y sextos, "partes de por medio", segundos graciosos, barbas o vejetes y músicos, que suelen aparecer en las listas de compañía en último lugar seguidos únicamente del personal auxiliar, tal y como podemos ver en la de la compañía con la que Antonio de Escamilla representó una de las partes de El Santo Rey D. Fernando, auto sacramental escrito por Calderón para el Corpus madrileño de 1671:

[Hombres]

Alonso de Olmedo, $1^{\circ}$ [galán]

Juan Fernández, $2^{\circ}$

Lorenzo García, $3^{\circ}$

Juan Antonio, $4^{\circ}$

Mateo de Godoy, barba

Antonio de Escamilla, gracioso [y autor]

Bernardo López, $2^{\circ}$ [gracioso]

Jerónimo de Peñarroja, $2^{\circ}$ barba y "de por medio"

Gaspar Real, músico

[Blas de] Navarrete, músico

Juan Gallego, arpista

Melchor, apuntador

Juan Luis, cobrador

Gabriel, guardarropa.

Ver en PÉREz PAstor, Cristóbal: Documentos para la biografía de D. Pedro Calderón de la Barca. Madrid, Fortanet-RAH, 1905, pp. 323 y 325. Citaré por Docs. Calderón.

\section{[Mujeres]}

María de Quiñones, $1^{a}$ [dama]

Bernarda Manuela, $2^{a}$

Manuela de Escamilla, $3^{\mathrm{a}}$

Manuela Fernández, $4^{\mathrm{a}}$

María de los Reyes, $5^{\text {a }}$

La mujer de Navarrete, música [Feliciana de Ayuso] 
La presencia de unos profesionales altamente cualificados se hizo aún más necesaria en las compañías de la corte dada la importancia que tuvo la música en el teatro cortesano español, verdadero impulsor del teatro musical, sobre todo porque la participación en estas obras de los miembros de las instituciones musicales al servicio de la Casa Real no pasó de anecdótica, corriendo siempre la interpretación de la música por cuenta de los miembros de las compañías profesionales que las representaban. Por ello, desde fechas muy tempranas autores de compañía y autoridades civiles mostraron una preocupación constante por contar con los mejores profesionales de los que se podía disponer, aunque ello llevase aparejado cuantiosos gastos. Músicos y arpistas de reconocido prestigio formarán parte, por tanto, de las compañías de Madrid desde principios del siglo XVII dado que la Villa y Corte, en tanto que capital de la Monarquía Hispánica, se convierte también en el centro de la vida teatral y a ella deben acudir anualmente en Pascua de Resurrección todos los miembros de la profesión cómica a fin de poder formalizar sus contratos ${ }^{3}$.

Perfectamente jerarquizados, la diferencia de cometidos entre los músicos de una compañía no siempre se especifica en los contratos que, por el contrario, sí suelen indicar que todos ellos estaban obligados a cantar y tañer guitarra y/o arpa, y aún a representar; es más, algunos músicos desarrollaron también una carrera como actores y otros parecen haber estado dotados de excelentes habilidades cómicas, aunque rara vez desempeñan en las obras un papel de importancia.

Siendo obligación del músico principal "poner los tonos" y "enseñar la música a los compañeros", no están tan claras las competencias del arpista que, por otra parte, y pese a esta denominación podía tañer también la guitarra o vihuela, ya que éste era el principal instrumento de la música teatral hispana, hasta el punto de que las propias obras teatrales pueden indicar mediante breves acotaciones los "puntos" o acordes que se deben emplear en cada caso ${ }^{4}$. Ello se debía a que "...la guitarra es un instrumento el más fauorable para nuestros tiempos que jamas se bio..." porque, además del "ahorro de la bolsa y de la pena”, es

“[...] acomodada y propia para cantar, tañer, dançar, saltar y correr, baylar y zapatear [...] cantando y representando mil amorosas pasiones con su ayuda. Es salsa para el contento, desterradora de pesares y cuidados, pasatiempo a los tristes, consuelo a los solos, alegria a los melancolicos, templanza a los colericos, da seso a los locos y enloqueçe a los sanos [...]"

Para colmo de ventajas "no la ofenden ninguna de las incomodidades que el delicado laud teme, no ay humo, ni calor, ni frio, ni humedad que la incomode [...] si presto se destempla, bien presto se torna

3 En 1658 don Gaspar de Haro, marqués de Liche y del Carpio, a cuyo cargo se encontraba la organización de los festejos reales, reorganiza todas las compañías que debían actuar en Madrid, que eran las que representaban también ante los reyes, formando cuatro que llamó "de la Fama" integradas por los profesionales más cualificados. El sistema se mantuvo tras la desaparición del Marqués, aunque finalmente terminó siendo muy oneroso para el Ayuntamiento madrileño. Ver BARRIONUEVo, Jerónimo de: Avisos. 2 vols. Madrid, Atlas, 1969, vol. II, p. 165; FlóREZ AsEnsio, María Asunción: “'Salgan racionales ruiseñores': Músicos de las compañías teatrales de Madrid durante el siglo xvII", en Revista de Musicología, Xxxi/1 (2008), pp. 41-78; y también "La Alcaidía del Buen Retiro y los festejos reales", en Anales del Instituto de Estudios Madrileños, XLVI (2006), pp. 71-99; "El marqués de Liche: Alcaide del Buen Retiro y "Superintendente" de los festejos reales", en Anales de Historia del Arte, en prensa.

4 El Baile del Zurdillo es excepcional en este sentido ya que se indican tres posiciones. Desde el primer verso debe tocarse " $f$ 5", es decir "por 5"; hacia la mitad del baile ( $f^{\circ} 39 r$ ) se indica " $f 2$ " mientras que el epílogo es " $f$ por +" (fo 40r). Ver Libro de Bailes de Bernardo López del Campo, Biblioteca Nacional (B.N.) de Madrid, Ms. 4.123, fo 37v-40r. 
a templar, si se rompe con dos sueldos se acomoda..."5. Se trataba, por tanto, de un instrumento dúctil y resistente, muy adecuado para la azarosa vida del teatro, que contaba, además, con otra ventaja ya que la guitarra barroca permitía a un instrumentista avezado, y sin duda los músicos de compañía lo eran, emplear diferentes técnicas según las necesidades de la obra. El hecho de que en algunos casos los músicos aparezcan mencionados en unos documentos como guitarristas y en otros como arpistas parece, pues, claro indicio de que podían tañer ambos indistintamente ya que ambos eran los instrumentos característicos de la música teatral española ${ }^{6}$.

El origen y formación de los músicos de compañía podía ser tan diverso como el desarrollo de su carrera dado que su oficio no les impedía trabajar como músicos de otras instituciones antes o después de su paso por el teatro ${ }^{7}$, al que, no obstante, por regla general parecen haber dedicado su vida profesional pese a que el importante papel que jugaron en él ha quedado oscurecido por el éxito que alcanzaron sus compañeras, las actrices-músicas. Lo cierto es que, pese a ocupar una posición intermedia dentro de las compañías, estos músicos desarrollaban un trabajo esencial para el éxito de las mismas y, por ende, contribuyeron de forma decisiva a su supervivencia y viabilidad.

Su importancia real en la vida teatral de la época se ve confirmada, además, por el hecho de que con frecuencia formasen parte del grupo de sobresalientes contratados por la Casa Real y por el Ayuntamiento para participar en representaciones de tanta relevancia institucional -política y religiosa- como los festejos palaciegos (con que se solemnizaban eventos importantes para la Monarquía) y los autos sacramentales del Corpus, una de las principales fiestas del mundo católico y la principal del calendario religioso español.

Ello implica que, pese a los escasos datos que nos han llegado sobre su formación y las dudas que su pericia profesional ha venido suscitando, estos músicos no sólo eran consumados intérpretes de guitarra y arpa sino que, además, poseían la destreza necesaria y suficiente como para interpretar y poner en práctica las novedades que los músicos de cámara al servicio de la Casa Real fueron introduciendo en el teatro musical hispano, ya que los mismos músicos y actores que representaban en los corrales interpretaban en la corte las elaboradas "fiestas reales" en las que tanta importancia tenía la música. No podemos, por tanto, descartar que si los actores- y especialmente las actrices- alcanzaron un notable dominio de las danzas reservadas inicialmente a los miembros de la corte, lo mismo sucediera en el caso de la composición e interpretación musical, siendo su destreza lo suficientemente notable como para poder participar junto con los músicos de la cámara real en conciertos privados ante los reyes.

5 BRICEÑo, Luis de: Metodo mui facilissimo para aprender a tañer la guitarra a lo español. París, Pierre Ballard, 1626. Cito por la edición facsímil de Minkoff (Ginebra, 1972), s.p.

6 Ver Flórez, Ma Asunción: Música teatral en el Madrid de los Austrias durante el Siglo de Oro, Madrid, ICCMu, 2006, pp. 89-91.

7 Es el caso de Baltasar Caballero, miembro de una familia de actores y músicos teatrales, que inicia su vida profesional como segundo músico en la compañía de su padre, Cristóbal Caballero, ejerciendo posteriormente como "musico thenor" de la catedral de Zamora, en la que permanece cerca de veinte años. En 1719, y debido posiblemente a la grave situación financiera por la que atravesaba la catedral, Caballero se incorpora a una de las compañías teatrales de la corte, pasando posteriormente una temporada al servicio del Duque de Osuna. También Alfonso de Flores, arpista de las compañías de la corte durante cerca de veinte años, terminó su vida profesional alejado del teatro ya que en 1710 entró como arpista de la catedral de Oviedo, en la que su hijo Lucas ejercía como organista. Ver Flórez Asensio, Ma Asunción: "Caballero, Baltasar" y "Flores, Alfonso de", en Diccionario Biográfico Español. Madrid, Real Academia de la Historia, en prensa. 
Lamentablemente, sólo en contadas ocasiones estos profesionales (instrumentistas y compositores), que aparecen en escena bajo el genérico Música o Músicos, representaban un papel y éste de poca importancia, aunque también los encontremos ocasionalmente interpretando personajes tradicionalmente asociados a la música tales como ciegos, barberos, sacristanes, etc. Lo habitual, no obstante, es que ocupen un plano secundario frente a los actores, y sobre todo actrices con notables habilidades musicales que acaparan el protagonismo de la música teatral en esta época, especialmente en el ámbito de la música vocal y la danza, ya que la música instrumental sí que parece haber sido terreno exclusivo de los músicos de la compañía ${ }^{8}$, salvo contadas excepciones como puede ser el caso de Mariana de Borja. Célebre como "representanta", música (cantante y arpista) y bailarina, "la Borja"9 desarrolló su carrera como tercera y cuarta dama de las compañías más importantes de la villa y corte, en la que actuó durante cerca de treinta años (desde 1652 hasta 1679). Su voz, clara, suave y sonora, según afirma su compañera Francisca López en la loa escrita por Juan Vélez para su zarzuela Los celos hacen estrellas, se vería potenciada por sus habilidades como arpista, muy apreciadas por el autor Diego Osorio, quien durante varias temporadas la contrató para representar y tocar el arpa. Las obras teatrales también nos han dejado noticias de sus habilidades como cantante e instrumentista, que le permitieron representar el papel de Orfeo (así lo afirma Félix Pascual en la loa escrita por Salazar y Torres para la presentación de esta compañía en Madrid hacia 1674) y no sólo en la comedia Euridice y Orfeo de Antonio de Solís, representada hacia 1655, sino incluso muy posiblemente en el auto sacramental El divino Orfeo (2a versión) escrito por Calderón para el Corpus madrileño de 1663, dado que una de las dos compañías contratadas fue la que dirigía José Carrillo, en la que Mariana era $4^{\mathrm{a}}$ dama. No debemos descartar que Calderón pensase en ella para el papel de Orfeo ${ }^{10}$ ya que, según se indica en las acotaciones, éste no sólo “...cuanto represente ha de ser cantado en estilo recitativo...” sino que, además, aparece en escena “...con un arpa al hombro, cantando...”" . Más explicita resulta aún la acotación de la

8 Como ya he afirmado en otro trabajo, en la música teatral hispana del Siglo de Oro se produjo una "[...] especialización musical sexual, de manera que se diferencian claramente dos ámbitos, vocal e instrumental, dominados con toda claridad -especialmente a partir de la segunda mitad del siglo- por mujeres y hombres respectivamente. El hecho de que en la segunda mitad del siglo, época en la que se impone el nuevo estilo monódico, la mayoría de las actrices importantes sean también afamadas cantantes, supone que la música vocal aparece como un campo musical fundamentalmente femenino, mientras que la composición y la música instrumental pertenecen al ámbito masculino", aunque limitado casi única y exclusivamente a los músicos de la compañía. Ver en Flórez, Ma Asunción: Música teatral en el Madrid de los Austrias..., op. cit., p. 475.

9 El hecho de que fuese hija del arpista Pantaleón de Borja constituye un magnifico ejemplo de la importancia que los antecedentes familiares tenían en la formación musical de las actrices de la época.

10 No obstante, es probable que fuese interpretado por Luisa Romero, contratada "[...] por sobresaliente en el auto del Divino Orfeo...", a quien el Ayuntamiento pagó 2.200 reales por su trabajo. Según el anónimo autor de la Genealogía, Luisa era "[...] zelebrada musica por los recitatiuos que los canto con primor [...]". No comparto la opinión de Sage que considera que el papel fue interpretado por Jerónimo de Heredia, quien quiso huir de la Corte presa del pavor al ver que era todo "cantado en estilo recitativo". Aunque a Heredia se le trajo desde Sevilla para hacer el papel de primer galán, creo mucho más probable que interpretase al Príncipe de las Tinieblas (un papel declamado), rival de Orfeo-Cristo por el amor de la Naturaleza Humana-Euridice. Ver SAGE, Jack: “Texto y realización de La estatua de Prometeo y otros dramas musicales de Calderón”, en Hacia Calderón. $1^{\circ}$ Coloquio Anglogermano (Exeter, 1969), Flasche, Hans (ed.), Berlin, Walter de Gruyter, 1970, pp. 37-52, p. 45; SHERGOLD, Norman D. y VAREY, John E.: Los autos sacramentales en Madrid..., op. cit., p. 189, y Fuentes para la historia del teatro en España II. Genealogía, origen y noticias de los comediantes de España, SHERGold, Norman D. y varey, John E. (ed.), Londres, Támesis Books, 1985, p. 470. Citaré por Genealogía.

11 La acotación no dice que sea el propio personaje el que tañe el arpa, clara alegoría de la "Cithara Iesu" cuya relación con la Cruz se hace explicita tanto de forma visual (".... en cuyo bastón vendrá hecha una cruz...") como auditiva ya que en el texto se establece una correspondencia entre los elementos de ambos: "[...] ha dispuesto [Amor] que labre / instrumento que al hombro 
mojiganga Los ciegos, también de Calderón y representada en 1670 con su auto Sueños hay que verdad son, en la que Mariana hace de ciego y aparece en escena cantando y tocando la guitarra ${ }^{12}$. También Elena Osorio, hija del autor Jerónimo Velázquez, tal y como la describe Lope en La Dorotea, constituye un caso excepcional ya que poseía numerosas habilidades musicales pues, además de cantar y tocar arpa y clavecín, componía tonos sobre textos propios y ajenos, incluidos los del propio Fénix:

\section{Bela: “¿Qué graciosa repetición! ¿Cúyo es el tono?.}

GERARDA: De la misma que lo canta" ${ }^{13}$.

Este protagonismo de las actrices ha permitido, cuando no favorecido, que las diversas y variadas funciones asignadas a estos músicos quedasen relegadas a un papel secundario pese a la importancia que todas ellas tenían para el correcto funcionamiento y el prestigio profesional de la compañía -especialmente en una época en la que el teatro se concebía como un espectáculo visual y auditivo del que la música formaba parte inseparable- puesto que iban más allá de la mera interpretación de la misma, ya fuese mediante la ejecución de las partes instrumentales y corales antes, durante y después de la representación teatral o acompañando el canto y baile de sus compañeros, tarea no siempre fácil dada la frecuencia con la que en el teatro hispano se alternan, e incluso superponen, las partes habladas y las cantadas, lo que exige la perfecta sincronización entre los músicos y los actores ${ }^{14}$, a los que, por otra parte, estos mismos músicos enseñaban y ensayaban las obras.

Resulta, pues, que pese a que actualmente se reconoce la importancia de la música en todo tipo de obras en el teatro del Siglo de Oro, ello no ha supuesto un interés por aquellos que se ocupaban de proveer

/ arrodillar me hace, / siendo cada clavija / un hierro penetrante, / cada cuerda un azote / y un golpe cada traste.". Ver el auto en la edición de Duarte, J. Enrique, en Alcalá-Zamora, José; y Díez-Borque, José Mã : Calderón de la Barca. Obras maestras. Madrid, Castalia, 2000, pp. 699-714, p. 711.

12 Para más detalles sobre la actividad profesional de Mariana de Borja ver FlóRez AsEnsio, Ma Asunción: "Borja, Mariana”, en Diccionario Biográfico Español. Madrid, Real Academia de la Historia, en prensa. Ver los contratos con el autor José Carrillo en Pérez Pastor,, Cristóbal: "Nuevos datos acerca del histrionismo español de los siglos XVI y XVII" (2 $2^{\mathrm{a}}$ serie), en Bulletin Hispanique, Xv (1913), pp. 300-315 y 428-444, pp. 309, 314 y 428 y la compañía de Carrillo en 1663 en PÉREz PASTOR,, Cristóbal: Docs. Calderón, p. 296. Ver la loa para Los celos hacen estrellas en la edición de SHERGOLD, Norman D., y VAREY, John E., Londres, Támesis Books, 1970, pp. 5-15, p. 9; el auto El divino Orfeo de Calderón en la ed. cit. de DuARTE, J. Enrique, pp. 700 y 711; la mojiganga Los ciegos en Lobato, Ma Luisa: Calderón de la Barca. Teatro cómico breve. Kassel, Reichenberger, 1989 , pp. 599-608 y la loa de Salazar y Torres en Farré Vidal, Judith: Dramaturgia y espectáculo del elogio. Loas completas de Agustín de Salazar y Torres. 2 vols. Kassel, Reichenberger, 2003, vol. II, pp. 571-585, p. 574.

13 Lope de Vega: La Dorotea. Cito por la edición de Blecua, José Manuel: Madrid, Cátedra, 1996, p. 212. En el debate que siguió a la cuarta sesión del coloquio internacional Images de la femme en Espagne aux xvIe et XviIe siècles (París, Presses de La Sorbonne Nouvelle, 1994), Danièle Becker destacó el hecho de que Lope atribuya al personaje de Dorotea formas líricas y musicales circulares, cerradas, acompañadas por el arpa y el clavecín, lo que favorece las actitudes graciosas y la emisión de la voz, mientras que Fernando, el poeta que le personifica, crea, recita y en ocasiones canta acompañándose con la guitarra, romances y formas abiertas que le permiten exprimir su creatividad.

14 La dificultad que supone hoy la interpretación alterna de fragmentos cantados y hablados ha sido señalada por González Marín, quien destaca cómo a las dificultades técnicas (por ejemplo: dar el tono al cantante) se añade el que este tipo de escenas "[...] chocan con nuestra idea de lo verosímil, que admite mejor que todos los personajes canten, en lugar de las complejas convenciones calderonianas [...]”. GonZÁLEZ MARín, Luis Antonio: "Recuperación o restauración del teatro musical español del siglo XVII", en La ópera en España e Hispanoamérica. CASAREs Rodicio, Emilio y TorRenTe, Álvaro (eds.), 2 vols., Madrid, ICCMU, 2001, vol. I, pp. 59-78, p. 61. 
la música de comedias, fiestas y autos, así como la de las obras breves que las acompañaban; es más, en ocasiones incluso se les ignora atribuyendo esta tarea tan esencial al autor de compañía pese a que numerosos contratos incluyen para el músico principal la obligación de "poner los tonos”, como también lo indican las propias obras teatrales, en las que los dramaturgos incluyen un elevado número de canciones tanto preexistentes como nuevas y/o creadas ex profeso para la obra.

Es cierto que en las fiestas cortesanas y en las representaciones del Corpus la música de la obra principal -así como la de la loa- solía encargarse a un músico al servicio de la Casa Real o al maestro de alguna de las numerosas capillas con que contaba la villa de Madrid, pero ello no debe hacernos olvidar que al músico principal de la compañía contratada competía la obligación de facilitar la música de todas las piezas breves que acompañaban a estas fiestas cortesanas y sacramentales, además de ocuparse de proveer la música de las representaciones "ordinarias" en los corrales, que incluían varias partes cantadas y danzadas tanto en las obras principales como en las piezas breves que las acompañaban, obras que formaban parte del repertorio que se representaba (al menos dos veces por semana) a los reyes en Palacio a modo de "particulares" 15 , y en las que la música tenía también un papel relevante ya que no sólo caracteriza a los personajes sino que contribuye, además, a potenciar la acción ${ }^{16}$, lo que explica el elevado número de canciones que pueden incluirse en una obra teatral, independientemente del género al que ésta pertenezca.

El amplio repertorio que cada temporada presentaban las compañías (“[...] 40 comedias, mas las que la compañía le pidiere, entrando en ellos entremeses, letras, bailes y lo demás a ello tocante [...]") ${ }^{17}$ requería, pues, una gran cantidad de música por lo que los músicos podían recurrir a dos procedimientos: acudir a fuentes preexistentes o, lo que es mucho más interesante, componer ellos mismos las obras necesarias para cada representación.

En el primer caso disponían de un amplio repertorio bien conocido por los espectadores y facilitado en muchas ocasiones por los propios dramaturgos, por lo que bastaba con citar sólo los versos iniciales ya que la música permitía fijar los textos en la memoria colectiva lo que facilitaba la tarea de los músicos de compañía. Pero, además, al ser la canción una forma de expresión importante en el teatro del Siglo de Oro, no sólo se cantaban sino que aparecen embebidas en el texto declamado, ya sea de forma literal

15 Eran representaciones privadas que desde el reinado de Felipe III se hacían en el Cuarto de la Reina todos los jueves y domingos, y también en algunas festividades.

16 Díez de Revenga ha señalado la importancia de la canción de tipo popular como elemento constitutivo del teatro del Siglo de Oro a partir de Lope, creador de su propio cancionero que intercala en sus obras dramáticas a modo intermedios líricos considerados por la mayoría de los estudiosos como "[...] elementos de suspensión de la tensión dramática [...]". Sin embargo, Fernández Guillermo destaca la estrecha relación que Lope establece entre las canciones y las secuencias poéticas, de tal forma que “[...] no solo asigna una función dramática a cada canción intercalada en una pieza, sino que, además, la articula con las secuencias poéticas [...]" de tal manera que "[...] lo que canta la gente encuentra resonancia en los sucesos que afectan a los personajes y en sus más hondos sentimientos [...]", por lo que "[...] refuerza puntos clave de la trama [...] crea mayor expectación e intensifica la emoción de determinadas escenas [...]”, opinión que comparto plenamente. DíEz DE ReVEnGA, Francisco J.: Teatro de Lope de Vega y lírica tradicional. Murcia, Universidad de Murcia, 1983, pp. 29 y 33; Fernández GuILlermo, Leonor: "Los intermedios líricos en la comedia de Lope de Vega: versificación, funciones y relaciones", en Teatro de palabras, 2 (2008), pp. 13-27.

17 Obligación de Andrés de Claramonte con los actores de su compañía en 1614. Casi cincuenta años más tarde, en 1660, Jerónimo Álvarez Vallejo firma un contrato para hacer en Zaragoza "[...] 80 representaciones sucesivas de las comedias que tiene puestas para este año, que son 40 [...]”. Ver ambos contratos en Pérez PAstor, Cristóbal: Nuevos datos acerca del histrionismo español en los siglos XVI y XVII. Madrid, Imprenta Revista Española, 1901, p. 150 (Claramonte) y "Nuevos datos acerca del histrionismo español en los siglos XVI y XVII" (2a serie), en Bulletin Hispanique, XVI (1914), pp. 458-487, p. 463 (Vallejo). 
o glosadas. Es igualmente frecuente que una canción bien conocida por todos origine una obra teatral compleja o una pieza breve, dado que permitía comunicar al público de manera breve y concisa el eje y pretexto de la trama, tal y como sucede en Peribáñez y el comendador de Ocaña de Lope, en la que no sólo se interpreta la cancioncilla popular sino que, antes de que sea cantada por un segador, es decir, por la Música, Lope la embebe en la parte declamada por Casilda, todo ello en la segunda jornada ${ }^{18}$. También Moreto se inspira en una canción popular ("Amor loco, amor loco / yo por vos y vos por otro") para su comedia Yo por vos, y vos por otro ${ }^{19}$.

Por otra parte, mediante la técnica del contrafacta se podía aprovechar su poder evocador y potenciar su impacto emocional sobre los asistentes a la representación ya que el grado de conocimiento y difusión de las canciones entre las diversas capas sociales que acudían al teatro era enorme, de ahí que en muchos casos una letra nueva se pudiese cantar "por el tono de", tal y como se indica en el Baile de la Forastera para el texto en el que la protagonista hace toda una declaración de intenciones, que, según la acotación ("Sale la graz[ios] a y canta lo sig[uien]te por el tono del desmayo" ${ }^{20}$ ), no es otro que la tonada de Juan Hidalgo "Del desmayo, del susto, del miedo" interpretada por Pocris ${ }^{21}$ en la tercera jornada de Celos aun del aire matan de Calderón, siendo idéntica la métrica de ambos textos.

Este rico repertorio de canciones que todos conocían, muchas de las cuales, lamentablemente, nos son hoy desconocidas ${ }^{22}$, podía presentarse en las obras teatrales bajo formas tan diversas como su procedencia ya que los músicos podían recurrir a obras populares o "popularizantes", es decir, obras en estilo popular reelaboradas o compuestas en la época, y también contaban con un amplio repertorio constituido por canciones de

18 Cito a Lope de Vega: Peribáñez y el Comendador de Ocaña por la edición de Marín, Juan Ma , Madrid, Cátedra, 2006, pp. 130 y 145. Para la canción de Peribáñez ver Díez De Revenga, Francisco J.: Teatro de Lope de Vega..., op. cit., pp. 74-77; García De EnTERría, M ${ }^{a}$ Cruz: "Función de la letra para cantar en las comedias de Lope de Vega: comedia engendrada por una canción”, en Boletín de la Biblioteca Menéndez Pelayo, XLI (1965), pp. 3-62, p. 22. Sin embargo, en La mujer de Peribañez, "comedia famosa de tres ingenios" de la segunda mitad del siglo XVII, sólo aparece el texto de la canción tradicional embebido en la respuesta de Casilda al Comendador en la $2^{\mathrm{a}}$ jornada. Ver La mujer de Peribáñez, en García Lamas, José Manuel; et al. (ed.), Ocaña, Centro de estudios sobre la Mesa de Ocaña, 1985, pp. 16-17 y 118.

19 La canción que da origen a la obra de Moreto, introducida ya en la primera jornada, parece ser un refrán o estribillo atribuido por Lope en su comedia La bella malmaridada (otra obra engendrada por una canción popular) a Montemayor ya que éste lo incluye en la Diana (1559); sin embargo figura como "Glosa agora nuevamente compuesta a un romance muy antiguo" en los Pliegos Poéticos Españoles de la Universidad de Praga. La canción parece haber gozado de gran popularidad, ya que aparece en diversas fuentes poéticas y teatrales a lo largo de los siglos XVI y XVII. Ver Alín, José María: El cancionero español de tipo tradicional. Madrid, Taurus, 1968, pp. 430-431; FrENK, Margit: Nuevo Corpus de la antigua lírica popular hispánica (siglos XV a XVII). 2 vols., México, Fondo de Cultura Económica, 2003, vol. I, pp. 507-508; MoReto, Agustín: Yo por vos, y vos por otro. BAE, vol. XXxIX, Madrid, Atlas, 1950, pp. 373-390, p. 376; Lope DE VEGA: La bella malmaridada en la edición de AndRÉs, Christian, Madrid, Castalia-Comunidad de Madrid, 2001, p. 35.

20 Libro de Bailes de Bernardo Lopez del Campo. Biblioteca Nacional de Madrid, Ms. 4123, fo 79r-80v.

21 Esta tonada de Pocris debió alcanzar una notable popularidad ya que forma parte de la Jácara con variedad de tonos, una "ensalada musical” compuesta por veintiún íncipits de célebres tonos. Ver LAmBEA, Mariano y JosA, Lola: “Jácara con variedad de tonos. Relaciones entre tonos humanos y música teatral en el siglo XVII", nº 9, s.p. Agradezco a los autores que amablemente me hayan facilitado este trabajo aun inédito. Ver Celos aun del aire matan en la edición de STroud, Matthew D., San Antonio, Trinity University Press, 1981, p. 146, y la música en la edición crítica de la ópera a cargo de BonAstre, Francisco, Madrid, ICCMU, 2000, pp. 153-157 y 432-439.

22 Aunque era frecuente la edición de las letras así como su amplia circulación manuscrita, no sucedía lo mismo con la música debido a que la impresión musical era mucho más cara y, además, no todo el mundo sabía leerla. Resulta significativo que de un total de 301 obras que contiene el manuscrito titulado Libro de tonos puestos en zifra de Arpa (Biblioteca Nacional de Madrid., M-2478) sólo se haya recogido la letra y música de los 75 primeros, así como el hecho de que se indique que algunos deben cantarse "por el tono de". 
nueva creación, debidas en muchos casos a los músicos al servicio de la Casa Real cuyas obras se interpretaban habitualmente en el teatro ya que, desde sus mismos inicios, el teatro moderno funcionó como un activo absorbente y rápido divulgador de canciones o "tonos". La inclusión de canciones ya conocidas por los espectadores tenía, además, una importante ventaja dado que facilitaba la labor de unos músicos siempre agobiados por el escaso tiempo del que disponían las compañías profesionales para estudiar un nuevos repertorio, obligadas como estaban por un público ávido de continuas novedades a cambiar con frecuencia las obras.

La integración de canciones preexistentes se vio favorecida por el hecho de que, desde sus inicios, el teatro español de la edad moderna se va a caracterizar por la presencia de la lírica tradicional a través de numerosas "letras para cantar" incluidas en las obras teatrales, lo que las convierte en auténticos depósitos de una parcela de la lírica española que se verá notablemente incrementada con las obras creadas dentro de la nueva corriente poética "seudo popular" o popularizante iniciada hacia 1580 por Góngora y Lope de Vega, dado que, una vez más, se trata de una poesía creada para ser cantada que enlaza directamente con aquellas canciones "populares" que en muchos casos no lo eran en sus orígenes sino que se trataba de obras de un poeta cuya identidad desconocemos pero que se habían convertido en populares porque el pueblo las cantó, difundió y conservó, haciéndolas suyas al aceptarlas colectivamente ${ }^{23}$.

En cualquier caso, las canciones preexistentes brindaban a los músicos de compañía enormes posibilidades ya que les permitían disponer de un repertorio rico y variado que podían reutilizar siguiendo diferentes pautas, tal y como hacían los músicos de cámara de la corte que no dudaban en servirse igualmente de la música teatral, pues no debemos olvidar que el trasvase de textos y melodías entre obras y repertorios era constante, aunque el tratamiento musical que recibían podía ser diferente según el medio al que fuesen destinados. Un buen ejemplo de ello lo constituye la tonada "Ya no les pienso pedir" -cuyo texto es el de un romance conservado en diversas fuentes manuscritas e impresas de la primera mitad del XVII- de la que se conservan tres fuentes musicales, dos polifónicas y una para voz solista ${ }^{24}$, que, pese a pertenecer a ámbitos distintos, comparten numerosos rasgos melódicos y rítmicos, por lo que es muy posible que todas ellas se basaran en un modelo común: una melodía preexistente bien conocida por todos. Resulta muy significativo que la única versión no teatral, la de Juan Blas de Castro, añada un estribillo que constituye el centro de interés de la composición al concentrar la más amplia variedad de técnicas e ingredientes estilísticos musicales, estribillo que contrasta por su tenue contrapunto con las frases musicales, prácticamente homofónicas, de la estrofa. Se trata de una técnica que veremos repetidamente en otros

23 Alín, José Ma : Cancionero tradicional. Madrid, Castalia, 1991, p. 13. Ver además los trabajos de DíEz DE REvENGA, Francisco J.: "Teatro clásico y canción tradicional”, en Cuadernos de teatro Clásico, 3, 1989, pp. 29-44; y Frenk, Margit: Corpus de la antigua lírica popular hispánica (siglos XV a XVII). Madrid, Castalia, 1990, y Poesía popular hispánica. 44 estudios. México, Fondo de Cultura Económica, 2000.

24 La primera versión polifónica es obra de Juan Blas de Castro y aparece en el Cancionero recogido por Claudio de la Sablonara (1625c). Las otras dos versiones son obra de un compositor anónimo y corresponden a la segunda jornada de Fortunas de Andrómeda y Perseo, fiesta cantada escrita por Calderón de la Barca para celebrar en 1653 los años de la reina Mariana de Austria. Ver en Etzion, Judith: El Cancionero de la Sablonara. Londres, Támesis Books, 1999, pp. CV-CVi y 96-99 (música); RoBledo, Luis: Juan Blas de Castro (ca. 1561-1631). Vida y obra musical. Zaragoza, Institución Fernando el Católico-Diputación Provincial, 1989, pp. 73 y 78, y pp. 215-220 (edición musical). Ver la edición facsímil (texto y música) de la obra de Calderón a cargo de MAestre, Rafael, Almagro, Museo Nacional del Teatro-Ministerio de Cultura, 1994, pp. 89-90 (texto) y 215-217 (música). 
cancioneros musicales como el Libro de Tonos humanos, que recoge varios ejemplos. Posiblemente uno de los más significativos sea la tonada "A las puertas del alcalde" ya que se trata de un baile muy famoso cuya primera cuarteta, que le da nombre, aparece o se cita con algunas variantes en numerosas piezas teatrales tales como los entremeses La renegada de Valladolid (anónimo) y La autora de comedias de Luis Vélez de Guevara, y el Baile de Lucrecia y Tarquino de Moreto. La versión del Libro de Tonos Humanos, atribuida al padre Correa $^{25}$, presenta la peculiaridad de que incluye un estribillo en forma de seguidilla que se canta dos veces en cada ocasión, la primera como sólo de tiple y la segunda como un "cuatro" que, como en el ejemplo antes citado de Juan Blas, contrasta por su textura contrapuntística con la estrofa, que es la que mantiene el texto popular y se interpreta mediante la homofonía entre las cuatro voces.

Tratándose de canciones populares, los músicos de compañía podían elegir, por tanto, entre la versión tradicional o una elaboración -polifónica o no- más o menos complicada de la misma hecha por algún músico conocido o por ellos mismos, pero manteniendo los perfiles melódicos originales que permitían un rápido reconocimiento por parte de los espectadores. Se trata de una técnica propiciada por los propios dramaturgos que pueden incluir estas canciones de forma literal pero que habitualmente las introducen con pequeños cambios (aunque manteniendo siempre los rasgos que permiten reconocerlas sin dificultad) que producen la ilusión de haber sido escritas expresamente para la obra en la que se incluyen, lo que explica, además, el difundido uso de estribillos ya que mediante la técnica de la glosa los dramaturgos escribían sus propias coplas para estribillos bien conocidos, tal y como hace Lope en Peribáñez al crear dos estrofas que concluyen en la que dio origen a la comedia y resume toda su trama:

\section{(CAnta un SEGADOR)}

$\begin{array}{ll}\text { [SEGADOR]: } & \text { La mujer de Peribáñez } \\ & \text { hermosa es a maravilla; } \\ & \text { el Comendador de Ocaña } \\ & \text { de amores la requería. } \\ & \text { La mujer es virtuosa } \\ & \text { cuanto hermosa y cuanto linda; } \\ & \text { mientras Pedro está en Toledo } \\ & \text { desta suerte respondía: } \\ & \text { "Más quiero yo a Peribáñez }{ }^{26} \\ & \text { con su capa la pardilla } \\ & \text { que no a vos, Comendador, } \\ & \text { con la vuesa guarnecida". }\end{array}$

25 Ver en Lambea, Mariano y Josa, Lola: La música y la poesía en cancioneros polifónicos del siglo XVII. Libro de Tonos Humanos (1655-1656). Vol. III. Madrid, CSIC, 2005, pp. 38-39 y 51-52 (texto) y 135-139 (música).

26 Estos últimos cuatro versos son los que inspirarán a Lope la comedia. Ver en ed. cit., p. 145. 
Es muy posible que en estos casos los músicos mantuvieran la melodía tradicional del estribillo introduciendo variaciones melódicas y/o armónicas que permitieran fundirlos con la música creada por ellos para las nuevas estrofas o, incluso, enlazar varios estribillos consecutivos para formar con todos ellos una tonada nueva, tal y como sucede en la segunda jornada de la comedia El maestro de danzar de Calderón, en la que para evitar que oídos indiscretos puedan escuchar la conversación de Leonor con Enrique (el galán que se hace pasar por maestro de danzar), Inés, criada de la dama, interpreta los estribillos de seis canciones populares seleccionados ex profeso por el dramaturgo para dar origen a una nueva canción en la que se alude a la situación de Leonor:

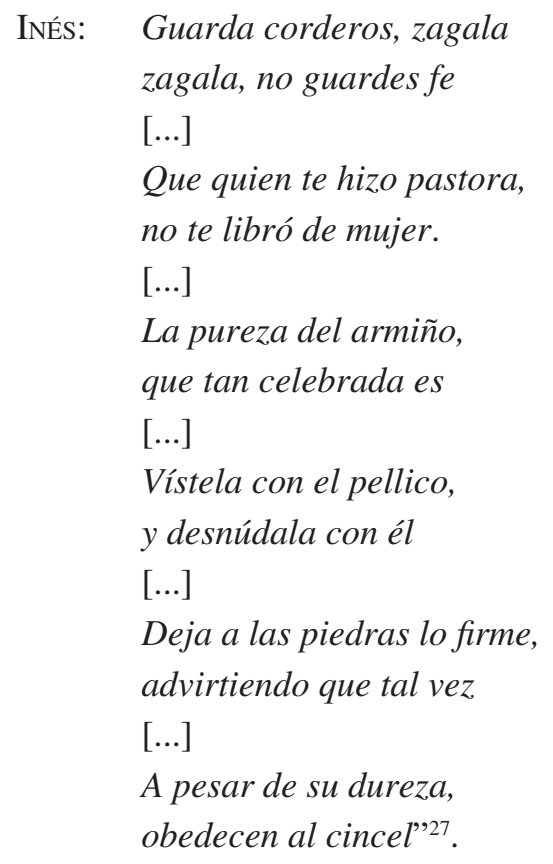

La importancia de los estribillos en la música española de la época queda confirmada por el hecho de que aparezcan igualmente en las canciones escritas por los dramaturgos a imitación de las populares, y ello se explica porque, al ser fácilmente reconocibles por el público, constituyen un elemento de unión importante entre las distintas parte de la comedia, motivo por el cual Calderón los utiliza de forma determinante en sus dos óperas aunque ya había experimentado con ellos en sus comedias y fiestas, en las que, dentro de una misma obra o incluso una escena, funde partes para cantar nuevas escritas ex profeso para la obra con estribillos de canciones populares o preexistentes bien conocidas por el público.

El rico repertorio de canciones preexistentes al que los músicos de compañía podían acudir incluía también un extenso catálogo de obras formado por canciones nuevas de diferentes autores que circulaban profusamente, en gran medida gracias al teatro ya que desde la primera mitad del siglo XVII éste se convier-

27 Cito por la edición de la $B A E$, Madrid, Atlas, 1945, pp. 77-97, pp. 86-87. 
te en uno de sus principales medios de difusión al insertarse en las obras teatrales canciones compuestas por eminentes músicos al servicio de la Corte ${ }^{28}$. Como ya había sucedido con las canciones populares, las más famosas o celebradas darán también origen a obras teatrales, aunque en este caso se trata casi siempre de piezas de teatro breve, fundamentalmente bailes dramáticos. La enorme difusión alcanzada por alguna de estas canciones explica que, para aprovechar el potencial nemotécnico de la música, en muchos casos se sustituyan los textos originales por otros creados ex profeso para la situación planteada en la obra, técnica que se aplica también a las tonadas teatrales, reutilizadas con las modificaciones pertinentes en obras de género y argumento completamente diferentes, tal y como podemos ver en el Baile de Júpiter y Calixto (anónimo), que incluye, entre otras, una parodia de la tonada "Esta, hermosa Diana", escrita por Juan Hidalgo para la primera jornada de la ópera Celos aun del aire matan en la que es interpretada por Pocris al inicio de la obra para delatar a Aura ante la diosa. En el baile ${ }^{29}$ la tonada es interpretada igualmente por una de las ninfas de Diana, pero los cambios introducidos en la segunda parte de la misma revelan la misma visión jocosa de los dioses olímpicos que podemos apreciar en las obras de Velázquez:

$\begin{array}{lr}\text { PocRIs: } & \text { Esta, hermosa Diana, } \\ \text { cuya incauta belleza, } & \text { Ninfa: Esta, hermosa Diana, } \\ \text { baldón es de tus montes, } & \text { cuia yncauta belleza, } \\ \text { oprobio de tus selvas, } & \text { valdón es destos montes, } \\ \text { es Aura, a quien tus ninfas, } & \text { y oprobio destas selvas, } \\ \text { al sacro culto atentas } & \text { Calixto es, que cansada } \\ \text { del puro amor que ensalzas, } & \text { de seruir de donzella, } \\ \text { del torpe que desprecias, } & \text { por sello de sus gustos } \\ \text { presentamos ante ti ... } & \text { ha querido ser dueña }{ }^{30} . \\ \text { (Celos aun del aire matan, I) (Júpiter y Calixto) }\end{array}$

Los ejemplos son muy numerosos ya que los dramaturgos demuestran una gran habilidad para introducir en sus obras citas y parodias de obras musicales preexistentes, teatrales o no, tal y como hace el anónimo autor del Baile del Gigante cristalino, en el que la tonada original ${ }^{31}$, una de las más célebres en la

28 Baste recordar que, según informa Tirso en su obra Los cigarrales de Toledo (Madrid, 1621), las letras, bailes y entremeses que acompañaron la representación de su comedia El vergonzoso en palacio "[...] fueron excelentes [...]" siendo autores de los mismos "[...] Juan Blas, único en esta materia", Alvaro [de los Ríos] "si no primero, tampoco segundo". Cito por la edición de VÁzQuez FernándeZ, Luis, quien apunta la posibilidad de que la comedia se representase hacia 1604 o incluso antes. Ver TiRso DE Molina: Los cigarrales de Toledo. Madrid, Cátedra, 1996, p. 219. Sobre Juan Blas y sus contemporáneos ver RoBLEDo, Luis: Juan Blas de Castro..., op. cit., pp. 19-58.

29 Ver el Baile de Júpiter y Calixto en el manuscrito 15.788 de la Biblioteca Nacional de Madrid, fo 40r-42v, fo 41r y Celos aun del aire matan en la edición crítica de la ópera ya citada a cargo de BonAstre, Francisco, pp. XLV (texto) y 3 (música).

30 El anónimo poeta juega aquí con el doble sentido de la palabra, que alude tanto a la pérdida de la virginidad de Calixto como al hecho de que la ninfa haga lo que le viene en gana pese a que su padre la " [...] tiene / en la escuela de Diana / puesta a ser donzella pagada por meses [...]" Baile de Júpiter y Calixto, $\mathrm{f}^{\mathrm{o}} 40 \mathrm{r}-40 \mathrm{v}$.

31 Posiblemente la que aparece como anónima en el Libro de Tonos Humanos y atribuida a Manuel Correa en el Cancionero de Onteniente. Ver Lambea, Mariano y Josa, Lola: Libro de tonos humanos. Vol. III, pp. 4546 y 101-103 (texto) y 292-294 (música); El Cançoner Musical d'Ontinyent. Climent, José (ed.), Ontinyent, Ajuntament d' Ontinyent, 1996, pp. 379-382 (transcripción musical) y 507-508 (texto). 
época a juzgar por el número de obras en las que se incluye, es modificada por el desconocido poeta para adaptarla al argumento del baile. Para ello, tras introducir la Música la primera estrofa y los dos primeros versos de la segunda, los dos actores protagonistas cantan otras tres de forma alterna, entremezclándolas con su texto recitado, pero sin respetar el orden en que aparecen en la tonada original ni tampoco el texto, en el que se introducen modificaciones ${ }^{32}$. Es evidente que estas modificaciones exigían también una adaptación de la música al nuevo contexto, para lo cual los músicos de compañía debían introducir algunos cambios en el original a fin de dar unidad al conjunto y lograr una cierta coherencia musical. Lamentablemente, aunque son numerosos los textos que nos han llegado, no podemos decir lo mismo de la música, que es prácticamente inexistente. Tenemos, sin embargo, un magnífico ejemplo en la Jácara con variedad de tonos ya que el anónimo compositor de esta pequeña obra, compuesta por veintiún fragmentos de tonos que se van alternado con versos declamados de nueva creación, “...llegó a variar algunos finales de los fragmentos de los tonos citados para alcanzar un mayor dinamismo musical y facilitar la expresividad y la fluidez del discurso" 33 , tal y como sucede en la cita de la tonada "Gigante cristalino" incluida en esta jácara, en la que se aprecian variaciones rítmicas, melódicas y armónicas ${ }^{34}$ respecto del original conservado en el Libro de Tonos Humanos.

La reutilización de canciones preexistentes, ya fuesen populares, "popularizantes" o de autor conocido, resultaba, por otra parte, muy eficaz dado que, al ser obras que el público podía reconocer fácilmente, permitían una interpretación muy flexible pues no sólo podían ejecutarse de forma integra o parcial, modificando alguno de sus elementos, ya fuese el texto o la música, sino que a ello se añadía la posibilidad de ser interpretadas por uno o varios solistas (que podían repartirse a su vez las diferentes estrofas, y no siempre en el orden establecido originalmente) o incluso por un coro, ya que las compañías profesionales contaban con los efectivos musicales necesarios para interpretar obras a varias voces, normalmente las que se corresponden con lo que en la época se denominaba coro alto (SSAT) que, por otra parte, no siempre serían todas ellas cantadas ya que también podían cantarse una o dos voces siendo interpretadas las restantes por instrumentos.

En cualquier caso, el elevado consumo musical de las compañías no podía cubrirse únicamente acudiendo a obras ya existentes sino que, en la mayoría de los casos, pues mayoritarias eran las representaciones en los corrales públicos, se necesitaba música específica para la obra a representar y eran los músicos de la compañía encargada de su puesta en escena los que debían componerla. No debemos pasar por alto, pues, que la mayor parte de la música de nueva composición que se oía en los teatros era creada por estos músicos ya que, tal y como reflejan las propias obras teatrales, los dramaturgos eran también fecundos autores de canciones teatrales y, de hecho, aunque pueden incluir en sus obras canciones preexistentes, en muchos casos la mayoría inventa sus propias canciones tal y como hace Moreto con la tonada "Toda la

32 Se trata de un procedimiento que el propio Correa había utilizado en parte al adaptar el texto original de Lope de Vega (una de las barquillas incluidas en La Dorotea) ya que selecciona sólo ocho de las diecinueve cuartetas del romance de Lope. Ver Baile del Gigante cristalino en Ms. 16.292 de la Biblioteca Nacional de Madrid (fo 5r-11r); LoPe DE VeGA: La Dorotea (Madrid, 1632), ed. cit. pp. 303-305.

33 Lambea, Mariano y JosA, Lola: “Jácara con variedad de tonos...”, s.p.

34 No 6, Ibídem, s.p. 
vida es llorar" (Ejemplos 1 y 2$)^{35}$, interpretada "Dentro" por la Música en la tercera jornada de su comedia Yo por vos, y vos por otro, ya citada. Esta tonada, que se canta entremezclada con las partes dialogadas, enlaza y complementa el tema de la canción popular que dio origen a la trama, y sirve de resumen a lo sucedido en la comedia además de para expresar los sentimientos de las protagonistas:

\section{(Cantan dentro)}

MúsicA: Toda la vida es llorar

por amar y aborrecer.

En dejando por volver,

y en volviendo por dejar.

Yo de mi amante celosa,

yo de un celoso oprimida,

una y otra es triste vida;

¿cuál será menos penosa? ${ }^{36}$

Pero además de para expresar los sentimientos de los personajes, los dramaturgos inventan canciones que sirven para potenciar la acción o, simplemente, para facilitar el lucimiento de las habilidades canoras de una determinada actriz. Una mezcla de todo ello podemos ver en cada una de las tres canciones ("Por su perdida esperanza", "Yo quiero bien" y "Tiernas lágrimas derrama"), una en cada jornada, incluidas por Moreto en su comedia Lo que puede la aprehensión $n^{37}$ que requería notorias habilidades vocales de la actriz protagonista, que era quien debía interpretarlas, ya que el eje de la acción lo constituye la "voz delicada" de su personaje, Fenisa, que provoca un ardiente amor en el duque de Milán, su primo, a quien “...el alma me ha robado / con la voz por el oído” pese a que nunca la ha visto. A todo lo anterior se añade la importancia que los géneros teatral-musicales van a ir cobrando a partir de la segunda mitad del siglo, en los que metros y estrofas se entremezclan con una libertad que no se encuentra en los textos declamados. Parece, pues, que los dramaturgos eran plenamente conscientes de la estrecha relación existente entre los cambios de versificación y los musicales ${ }^{38}$, por lo que también lo

35 Agradezco a Luis Robledo la transcripción de la tonada para este trabajo.

36 Ver ed. cit., p. 385. La tonada fue reutilizada en la comedia burlesca Los amantes de Teruel de Vicente Suárez de Deza (Parte primera de los donayres de Tersicore, Madrid, 1663). Se conserva la música en el Manuscrito Novena, p. 334. Ver Fuentes para la historia del teatro en España IX. Comedias en Madrid: 1603-1709. Repertorio y estudio bibliográfico. VAREY, John E. y Shergold, Norman D. (ed.), Londres, Támesis, 1989, p. 54; Stein, Louise K.: Songs of mortals. Dialogues of the Gods: Music and Theatre in Seventeenth Century Spain. Oxford, Clarendon Press, 1993, p. 401. Agradezco a la Congregación de Ntra. Sra. de la Novena y al Museo del Teatro de Almagro que me hayan facilitado copia de esta tonada.

37 Cito por la edición de la $B A E$ vol. XXxix, Madrid, Atlas, 1950, pp. 167-186, pp. 169, 176 y 184-185.

38 Posiblemente el caso más representativo lo constituye Quiñones de Benavente, creador del entremés cantado o baile entremesado, un género teatral-musical caracterizado precisamente por su riqueza métrica y estrófica en el que, como ha señalado Bergman, "[...] confluyen palabra, música y movimiento escénico [...]", y cuya importancia en el desarrollo del teatro musical español es aún más relevante si tenemos en cuenta que abre el camino a toda una serie de géneros, tales como las loas y jácaras entremesadas y las mojigangas dramáticas, en los que se produce una fusión de la palabra con la danza y el canto. La fluidez, adaptabilidad y variedad de metros utilizados por Quiñones de Benavente en estas pequeñas obras es tal que apenas hacen perceptible al espectador - $\mathrm{o}$ al lector- que se trata de un texto en verso. Para Bergman esta riqueza métrica de su obra, tan diferente a la 
serían los músicos de compañía para los que los cambios de versificación, lejos de ser un inconveniente, constituirían una especie de guión que les permitía elegir entre los diversos procedimientos musicales aquellos que mejor pudieran adaptarse a la forma y contenido del texto, máxime si tenemos en cuenta que se trata de una música funcional, siempre en estrecha dependencia de un texto poético concebido para que funcionase acústicamente sobre el escenario. Lamentablemente, los criterios que servían a los compositores para elegir entre uno u otro procedimiento a la hora de poner música a un texto nos son tan desconocidos como los que utilizaban los dramaturgos para decidirse por uno u otro metro, y no sólo en los textos declamados sino también en los que expresamente debían ser cantados. No podemos descartar, por tanto, que a la hora de poner música al amplio repertorio que debía presentar cada temporada su compañía, los músicos recurriesen a una serie de fórmulas más o menos prefijadas, aunque éstas pudiesen perjudicar la calidad de la obra. No obstante, su trabajo se vería facilitado por el hecho de que a lo largo de todo el siglo XVII los "tonos" fueron asentando una serie de rasgos estereotipados tales como ritmos característicos en los que destaca el uso constante de la hemiolia, determinados diseños melódicos, giros armónicos y fórmulas cadenciales que constituían un estilo musical típicamente español, muy del gusto de un publico mayoritario. Ello explicaría que la supuesta imperfección de las obras destinadas a los corrales pudiese venir impuesta por el propio sistema más que por una falta de pericia de los compositores, ya que los frecuentes cambios de obra y los pocos ensayos exigían rapidez en la composición y obras que fuesen fáciles de aprender, sin olvidar su adaptación al gusto mayoritario del publico de los corrales, formado por miembros de todas las clases sociales pero en el que predominaba el "vulgo", un tipo de espectador que se guía por su gusto particular y no por cuestiones estéticas más o menos elaboradas, por lo que podemos suponer que, al igual que para Lope, también para los músicos de compañía primaba más el rendimiento teatral y económico de una obra que su función estética dado que “...como las paga el vulgo, es justo/ hablarle en necio para darle gusto" 39 .

De todo lo anteriormente expuesto se desprende que, pese al papel aparentemente secundario desempeñado por los músicos de compañía en el teatro hispano, ello no debe hacernos pensar que éste era insignificante o muy reducido, pues, en tanto que creadores e intérpretes de la música que se hacía a diario en los corrales ante un publico tan variopinto como impredecible y exigente, de gustos muy variados, todos los cuales debían contentar, fueron ellos los que con su actividad cotidiana contribuyeron al desarrollo de la música teatral de la época.

Su importancia, sin embargo, no se limita al papel jugado en los teatros públicos, pues no debemos olvidar que su formación musical les permitió afrontar con éxito las innovaciones musicales introducidas en el teatro cortesano por los músicos al servicio del rey ya que, pese a la importancia de los músicos de

utilizada en las comedias, se debe en gran parte a que el metro cambia cuando cambia la melodía, influyendo también la música en la frecuente inclusión de versos irregulares. Ver Bergman, Hanna E.: Luis Quiñones de Benavente y sus entremeses. Madrid, Castalia, 1965, pp. 190 y 259 y la "Introducción" a su edición de Ramillete de entremeses y bailes. Madrid, Castalia, 1970, p. 23. Ver también la "Introducción" de ANDRÉs, Christian, a su edición de los Entremeses de Quiñones de Benavente, Madrid, Cátedra, 1991, p. 39; y Flórez, Ma Asunción: Capítulo III.1 de Música teatral en el Madrid de los Austrias..., op. cit., pp. 171-225.

39 Lope de Vega: Arte nuevo de hacer comedias. Cito por la edición de García SANTO-Tomás, Enrique, Madrid, Cátedra, 2006, p. 133. 
la corte en el desarrollo y difusión de una forma musical tan ligada al teatro como el tono o tonada (tanto en su manifestación de canción polifónica, predominante en la primera mitad del siglo, como en la tonada a sólo de la segunda mitad del siglo, vinculada ya plenamente al teatro), lo cierto es que fueron los músicos de las compañías profesionales los que no sólo interpretaron estas obras sobre el tablado, sino que en ocasiones ellos mismos las compusieron sustituyendo en este cometido a afamados músicos al servicio de la Casa Real o de alguna de las capillas de la corte, tal y como sucedió en el Corpus de 1673, cuando Gregorio de la Rosa y Gaspar Real, músicos principales de las compañías de Félix Pascual y Manuel Vallejo respectivamente, pusieron “...las músicas de las dos compañías en lugar del maestro [Cristóbal] Galán..." ${ }^{40}$, por aquel entonces maestro de capilla de las Descalzas Reales ${ }^{41}$ y uno de los compositores de mayor fama y prestigio de la segunda mitad del XVII ${ }^{42}$. Por otra parte, la costumbre de que fuese el músico principal de la compañía que actuaba el que pusiese los tonos de las piezas breves de una fiesta cortesana o de un auto sacramental parece claro indicio de un reconocimiento implícito de su talento como compositores. Es muy posible, por tanto, que algunas de las tonadas teatrales que nos han llegado como anónimas pudiesen ser obra de estos músicos de compañía. En este sentido creo que no resulta excesivamente arriesgado suponer que la tonada anónima “¡Ay, que soy tamborilero de gala y primor!”, conservada en diversas fuentes ${ }^{43}$. pudiese ser obra de Gaspar Real o de Gregorio de la Rosa, músicos principales respectivamente de las compañías de Antonio de Escamilla y Manuel Vallejo en 1672, año en el que se representó Fieras afemina amor de Calderón de la Barca, a cuyo fin de fiesta pertenece esta tonada, que fue interpretada por Manuela de Escamilla ${ }^{44}$ : "Salió Manuela de Escamilla con un tamborilillo, cantando y bailando las siguientes coplas":

40 El Ayuntamiento pagó los acostumbrados 1.000 reales, 500 a cada músico, por este trabajo. Los autos que Calderón escribió para el Corpus de ese año fueron El arca de Dios cautiva, cuya música habría compuesto Gaspar Real ya que se pagaron 1.100 reales a Vallejo por los vestidos de "[...] dos niñas de diez años de anjeles [...]", que posiblemente serían las que hicieron a los niños que -según la Memoria de apariencias- aparecían en dos de los carros de este auto, por lo que Rosa habría compuesto la del otro, titulado La vida es sueño. Ver Shergold, Norman D. y VArey, John E.: Los autos sacramentales en Madrid..., op. cit., pp. 255-256 (cuentas), 263 (memoria) y 268.

41 Ocupó este puesto desde 1667 a 1680, año en el que fue nombrado maestro de la Real Capilla. Galán compuso la música de los autos representados en Madrid en 1664, 1671, 1672, 1674 y 1675. Ver Shergold, Norman D. y VAREY, John E.: Los autos sacramentales en Madrid..., op. cit., pp. 184, 242, 246, 279 y 304. Para su trayectoria profesional ver LoLo, Begoña: "Galán, Cristóbal", en Diccionario de la Música Española e Hispanoamericana, Emilio Casares (Coord.), Madrid, SGAE, 1999, vol. v, pp. 317-319.

42 En 1681 Miguel de Irizar, maestro de capilla de la catedral de Segovia desde 1671, solicita a uno de sus corresponsales le envíe villancicos "[...] con las calidades [...] de ser de este año y las letras [...] que sean buenas y nuevas [...]", quien le contesta que "[...] no hay otro maestro que el maestro Galán en Madrid que componga, y es el hombre mas estricto que he conocido en mi vida en orden a dar papeles porque ni con su padre se da a partido.". LóPEZ-CALO, José: "Corresponsales de Miguel de Irizar", en Anuario Musical, XVIII (1963), pp. 197-222, p. 203.

43 Catedral de Burgos: Ms. Bu 57/29; Biblioteca Nazionale Marciana (Venecia): Ms. It. Iv, 470=9994/fols. 1r-4r. Ver en García Garmilla, Patxi: Música a lo Divino y a lo Humano. 141 Obras del Archivo de la Catedral de Burgos (siglos XVII y XVIII). Zarauz, Catedral de Burgos-Aurora Boreal, 2008, pp. 224-225, quien publica una transcripción de la obra.

44 Manuela de Escamilla era $3^{a}$ dama en la compañía de su padre: Antonio de Escamilla. En el fin de fiesta apareció con un "vestido de hombre" de brocado encarnado y plata con "manto, tonelete y calçadillos" confeccionados en brocado celeste y oro. Ver la lista de ambas compañías en PéRez PAstor, Cristóbal: Docs. Calderón, p. 329. Para mayor información sobre la representación de Fieras afemina amor ver Fuentes para la historia del teatro en España XXIX. El teatro palaciego en Madrid: $1586-1707$. Estudio y documentos, Greer, Margaret R. y varey, John E. (ed.), Londres, Támesis, 1997, pp. 34-70 y 106.; FLóREz, Mª Asunción: "La Alcaidía del Buen Retiro...", op. cit., pp. 83-84. 


$\begin{array}{ll}\text { Manuela: } & \text { ¡Ay que soy } \\ & \text { tamborilero de gala y primor! } \\ & \text { Con tres pájaros la Fiesta } \\ & \text { hermosamente empezó, } \\ & \text { y quiero que la corone } \\ & \text { otro pájaro mayor. } \\ & \text { ¡Ay que soy } \\ & \text { Tamborilero de gala y primor } !^{45}\end{array}$

Creo, por tanto, que sólo el escaso número de partituras con atribución clara conservadas puede explicar por qué su contribución a la historia de la música ha pasado hasta ahora desapercibida, e incluso ignorada, pese a que con su quehacer cotidiano en las compañías contribuyeron de manera decisiva a la propia supervivencia de las mismas. No obstante la escasez de fuentes conservadas, la documentación de la que disponemos permite afirmar que los músicos de compañía podían alcanzar una gran pericia, compitiendo -como ya hemos visto- con músicos al servicio del rey o de alguna de las capillas más importantes de la Villa, competencia que se hizo más evidente a partir de la segunda mitad del siglo cuando se encarga a los músicos de compañía escribir música nueva para obras que originalmente habían sido musicadas por compositores considerados en un principio como más prestigiosos ${ }^{46}$ por estar ligados a las instituciones musicales de la corte. La trayectoria seguida por algunos músicos de compañía tan relevantes como Juan de Serqueira (o Sequeiros) y Manuel de Villaflor, y en menor grado por Miguel Ferrer y Alfonso de Flores, de todos los cuales sí se han conservado algunas composiciones, así lo confirma. El primero de ellos, considerado por Stein “...el músico más prestigioso y de mayor talento del teatro musical de su tiempo...”47, permaneció ligado de forma ininterrumpida durante más de cuarenta años a las compañías de la corte, a la que llegó en 1676 desde Granada por petición expresa del autor Manuel Vallejo para que participase en las fiestas del Corpus, convirtiéndose a partir de 1682, y hasta su retirada en 1720, en compositor habitual de la música del auto asignado a su compañía, ya fuesen reposiciones de Calderón o autos nuevos, como Gedeón humano y divino de Jacinto Ibáñez, representado en 1687, al que pertenece su tonada "Oíd el

45 Cito por la edición de Wilson, Edward M., Kassel, Reichenberger, 1984, pp. 215-216. El texto de la tonada conservada en la Catedral de Burgos coincide plenamente con el de la fiesta. La tonada fue reutilizada en la anónima Mojiganga de la Negra. Ver Stein, Louise K.: Songs of Mortals..., op. cit., p. 369.

46 Sin embargo, los tonos humanos (algunos teatrales como "Deidades del abismo" de Euridice y Orfeo de Solís) y villancicos de músicos tan apreciados como Juan del Vado, Cristóbal Galán o el mismo Juan Hidalgo son considerados por Constantijn Huygens, alto funcionario de la corte del Príncipe de Orange y músico aficionado educado en el estilo francés, como "fort Africaine", por lo que le parece que estos "airs Espagnols" o "tonos humanos-bestiados [...] ad nauseam sufficit d'avoir veu à quoy est decheu le beau génie Espagnol, qui a autrefois inspiré les grandes ames des Seneques, des Lucains [...]”. Muy distinta es la opinión de su corresponsal, Sébastien Chièze (embajador del Príncipe de Orange en Madrid), para quien "Los tonos, Señor, son muy Griegos, pero en la garganta de los músicos de acá, y en sus enredados parosismos, no les falta gracia, mayormente siendo ayudados de harpas, vihuelas y xirimias [...]". Dado que estos tonos eran interpretados en muchas ocasiones por los músicos teatrales es posible que tan entusiasta opinión se refiera también a ellos. RASCH, Rudolf: "Music in Spain in the 1670s through the eyes of Sébastien Chièze and Constantijn Huygens", en Anuario Musical, 62 (2007), pp. 97-124, pp. 111 y 113-114.

47 Stein, Louise K.: "Serqueira de Lima, Juan", en Diccionario de la Música Española e Hispanoamericana, Emilio Casares (Coord.), Madrid, SGAE, 2002, vol. 9, pp. 937-938. 
pregón que divulgar manda"48. Muy apreciado igualmente en palacio desde que en 1679 puso la música del fin de fiesta de Siquis y Cupido de Calderón ${ }^{49}$, afortunadamente, y a diferencia de lo ocurrido con otros músicos de compañía, sí tenemos algunos ejemplos de la música compuesta por Sequeiros para los corrales, siendo posiblemente una de más populares la tonada "Herbolario soy, señores", escrita originalmente para el Baile del herbolario y reutilizada en lo que parece ser una secuela: El baile del herbolario nиevo (c. 1685) $)^{50}$. Trayectoria similar fue la que siguió también Manuel de Villaflor, aunque su carrera en las compañías de la corte fue más breve ya que se vio truncada por su temprana muerte en 1707. Desde su llegada a Madrid en 1688, Villaflor se convierte, junto con Sequeiros, en uno de los principales músicos teatrales, encargándose — al menos desde $1691^{51}$ — de poner igualmente la música de los autos que cada año representaba su compañía, participando también en varias representaciones palaciegas. Como en el caso de Sequeiros, se han conservado varias tonadas suyas compuestas, posiblemente, para obras breves ${ }^{52}$. Aun más breve fue la carrera de Miguel Ferrer, músico de las compañías de la corte entre 1692 y 1700 , del que nos han llegado algunas obras, entre ellas dos tonadas para El Austria en Jerusalem de Bances Candamo ${ }^{53}$. Por lo que se refiere al ya citado Alfonso de Flores, arpista en las compañías de Madrid desde 1688 hasta 1709, se han conservado tres tonadas suyas en la Biblioteca Sutro de San Francisco ${ }^{54}$.

Los músicos arriba citados formaban, junto con el arpista Juan Bautista Chavarría, un grupo profesional cuyos miembros — estrechamente relacionados entre sí a lo largo de varios años, incluso por lazos familiares ${ }^{55}$ - dominarán la música teatral durante la última década del siglo, culminando con ellos una

48 Ver SteIn, Louise K.: Songs of Mortals..., op. cit., p. 389 y “Serqueira...”, p. 938. Sabemos con certeza que compuso la música de los dos autos representados en 1682, Andrómeda y Perseo y Mística y Real Babilonia, ambos reposiciones de Calderón, ya que en las cuentas de gastos de ese año figura el pago al músico de 1.100 reales "[...] por la composición de la musica p[a]ra los autos [...]" Archivo Municipal de la Villa (A.M.V..), Secretaría, 2-425-41.

49 Fuentes para la historia del teatro en España I. Representaciones palaciegas: 1603-1699. Estudio y documentos. SHERGOLD, Norman D. y VAREY, John E. (ed.), Londres, Támesis Books, 1982, p. 82. Citaré por Fuentes I.

50 Stein, Louise K.: Songs of Mortals..., op. cit., p. 382 y "Serqueira...”, p. 938. Ver también Flórez Asensio, Mª Asunción: "Sequeiros, Juan de", en Diccionario Biográfico Español. Madrid, Real Academia de la Historia, en prensa. Hay edición moderna de la tonada en Querol Gavaldé, Miguel: Música Barroca Española IV. Canciones a solo y dúos del siglo XVII. Barcelona, CSIC, 1988, pp. 37-39. El Baile del Herbolario se conserva en el Ms. 15.765 de la Biblioteca Nacional de Madrid.

51 Según las cuentas de ese año se le pagaron 500 reales "[...] por la composicion de la musica del Auto de su compañía [...]". A.M.V.: Secretaría, 2-198-17. Ver además FlóRez AsEnsio, Ma Asunción: "Villaflor, Manuel”, en Diccionario Biográfico Español. Madrid, Real Academia de la Historia, en prensa; y Stein, Louise K.: "Villaflor, Manuel de", en Diccionario de la Música Española e Hispanoamericana, Emilio Casares (Coord.), Madrid, SGAE, 1999, vol. 10, p. 909.

52 Las fuentes que han conservado el mayor número de tonadas atribuidas a Villaflor son dos manuscritos: el Ms. 13.622 de la Biblioteca Nacional de Madrid, que contiene catorce tonadas suyas, cinco de las cuales también aparecen en la manuscrito SMMS m1 de la Biblioteca Sutro de San Francisco, en el que hay diecisiete canciones de Villaflor, solo siete de las cuales se han conservado en otras fuentes. Ver KoEgel, John: "Nuevas fuentes musicales para teatro, danza y salón de la Nueva España", en Heterofonía, 116-117 (1997), pp. 9-37, pp. 28-31.

53 La comedia se estrenó en Valladolid el 16 de enero de 1695, por lo que podría ser la música original ya que Ferrer no figura en ninguna de las compañías de Madrid entre los años 1695 y 1697. Ver la "Introducción” de Morr, Duncan W. a su edición del Theatro de los Theatros de los passados y presentes siglos de Francisco Bances Cándamo, Londres, Támesis Books, 1970, p. XXXII. Ambas tonadas, "Ay mísera de ti Jerusalem" (en sus dos versiones: dúo para tiples y sólo de tiple) y "Salve Santa ciudad" (un cuatro para coro alto: s 1, 2, A, T), se conservan en el manuscrito 13.622 de la Biblioteca Nacional de Madrid. Ver CABALLERO, Carmelo: "El manuscrito Gayangos-Barbieri”, en Revista de Musicología, 12 (1989), pp. 199-268, pp. 226 y 263 ("Mísera”) y 260 (“Salve”). Ver también Stein, Louise K.: Songs of Mortals..., op. cit., pp. 368 y 398.

54 Manuscrito smms m1. Las obras que aparecen atribuidas a Flores son las números 43, 49 y 95. Ver KoEgEL, John: "Nuevas fuentes musicales...", op. cit., pp. 28-30.

$55 \mathrm{Si}$, como afirma el anónimo autor de la Genealogía, la madre de Alfonso de Flores era María de la O, hija de Toribio de Bustamante y María de los Santos, este arpista no sólo pertenecería a una de las dinastías cómicas más importantes del siglo XVII, 
tendencia que se puede observar ya desde mediados de siglo, cuando la música de los teatros madrileños pasa a estar en manos de unos pocos artistas tales como Tomás de Nájera, José Antonio Quevedo, Francisco de San Miguel y Ambrosio Duarte, que desarrollan su carrera en la década de 1650, aunque Duarte la prolongará hasta mediados de la década siguiente, en la que destacan, además, Gaspar Real y Gregorio de la Rosa, ya citados, y los arpistas Marcos Garcés (apodado Capiscol) y Juan de Malaguilla, todos los cuales continuaron trabajando en Madrid en la década de 1670 en la que aparecen Blas de Navarrete como segundo músico y Juan de Sequeiros, quien dominará la década siguiente en compañía del arpista Juan de Malaguilla. A partir de 1690 la música teatral de la villa y corte será asumida por Juan de Sequeiros y Manuel de Villaflor, como músicos principales, y los arpistas Juan Bautista Chavarría y Alfonso de Flore ${ }^{56}$, formando indistintamente pareja, aunque lo más habitual será la asociación Villaflor-Flores y Sequeiros-Chavarría ${ }^{57}$. Las listas de compañía de esta última década revelan, además, la constante presencia de Villaflor en las dirigidas por Agustín Manuel de Castilla y Carlos Vallejo, y lo mismo podemos decir respecto a Sequeiros y los autores Damián Polope y Juan de Cárdenas, de lo que se desprende que existía una relación estable entre autor y músico principal, mientras que el arpista solía cambiar de una a otra compañía ${ }^{58}$ aunque la relación profesional debía ser satisfactoria ya que cuando Chavarría acepta en 1703 la "autoría" de la compañía de Cárdenas ${ }^{59}$, Sequeiros permanecerá en ella como músico principal hasta la retirada de Chavarría en 1709. Idéntica situación se produce al asumir Villaflor en $1702^{60}$ la autoría de la otra compañía de Madrid, en la que Flores aparece como arpista.

La trayectoria profesional de estos músicos nos permite apreciar cómo supieron adaptarse a los cambios que se fueron operando en la música teatral hispana desde la segunda mitad del xvII, cada vez más influida por modelos foráneos, especialmente italianos, que en muchos casos ellos mismos pusieron

sino que estaría emparentado con Manuel de Villaflor, cuya mujer, la actriz Sabina Pascual, era hija de Manuela de Bustamante, hermana de la madre de Flores, por lo que éste y Sabina serían primos hermanos. Ver Genealogía, p. 418.

56 Ver Flórez Asensio, Ma Asunción: "Salgan racionales ruiseñores...", pp. 56-78; y también "Chavarría, Juan Bautista", "Duarte, Ambrosio", "Garcés, Marcos", "Malaguilla, Juan de", "Nájera, Tomás de", "Navarrete, Blas de", "Real, Gaspar", "Rosa, Gregorio de la", "Sequeiros, Juan de" y "Villaflor, Manuel" en Diccionario Biográfico Español, Madrid, Real Academia de la Historia, en prensa. Ver también en FerRer VAlls, Teresa (Dir.), Diccionario biográfico de actores del teatro clásico español (DICAT), Kassel, Reichenberger, 2008.

57 Villaflor y Flores aparecen como músico y arpista, respectivamente, de la compañía dirigida por Agustín Manuel de Castilla en 1691, 1693 y 1694, continuando en la misma los tres años siguientes (1695 a 1697) cuando, tras la muerte del autor, la compañía pasó a ser dirigida por Carlos Vallejo. La pareja Sequeiros-Chavarría formará parte de la compañía dirigida por Damián Polope en 1691 y desde 1693 a 1695, continuando en la misma los dos años siguientes cuando, tras la muerte de Polope y la renuncia de su viuda, Andrea de Salazar, la compañía pasó a ser dirigida por Juan de Cárdenas. Ver FlóRez AsEnsio, Mª Asunción: "Salgan racionales ruiseñores...", pp. 75-78.

58 Chavarría aparece con Villaflor en la compañía de Agustín Manuel en 1690 y 1692 y en la de Vallejo en 1698 y 1699 , pasando Flores esos mismos años a las de Polope y Cárdenas, en las que se incluye como segundo músico a Ferrer. Ver FLóREZ AsENSIO, Ma Asunción: "Salgan racionales ruiseñores...”; pp. 75-78.

59 Tras la desaparición de Cárdenas la "autoría" de su compañía pasó brevemente por varias manos hasta que finalmente fue el propio Chavarría, que se había retirado de las tablas, quien se hizo cargo de la misma, con la que representó uno de los autos del Corpus madrileño, que ese año fueron nuevamente reposiciones de Calderón: La cura y la enfermedad y El orden de Melquisedec. A.M.V.: Secretaría, 2-201-2.

60 El 18 de febrero de 1703 se requiere a Manuel de Villaflor “[...] autor de una de las compañías de comedias de esta corte [...]" y al resto de sus compañeros para que no salgan de Madrid. No sabemos los motivos por los que Villaflor asumió la autoría de una de las compañías de Madrid, pero de este requerimiento se desprende que había ejercido como tal ya en 1702. Ver A.M.V.: Secretaría, 2-201-2. 
en práctica pero manteniendo siempre unos rasgos que caracterizan a la música teatral española desde principios del siglo tales como la importancia concedida al texto, la riqueza rítmica, la constante presencia de la música vocal de cámara, que, en muchos casos, no sólo influye sino que se transmite a través del teatro, y, sobre todo, la pervivencia de lo popular o "popularizante”. Esta música de raigambre típicamente hispana sobrevivirá, cierto que con dificultades, en algunos géneros teatrales a los nuevos gustos que se van a imponer tras la llegada de la dinastía borbónica.

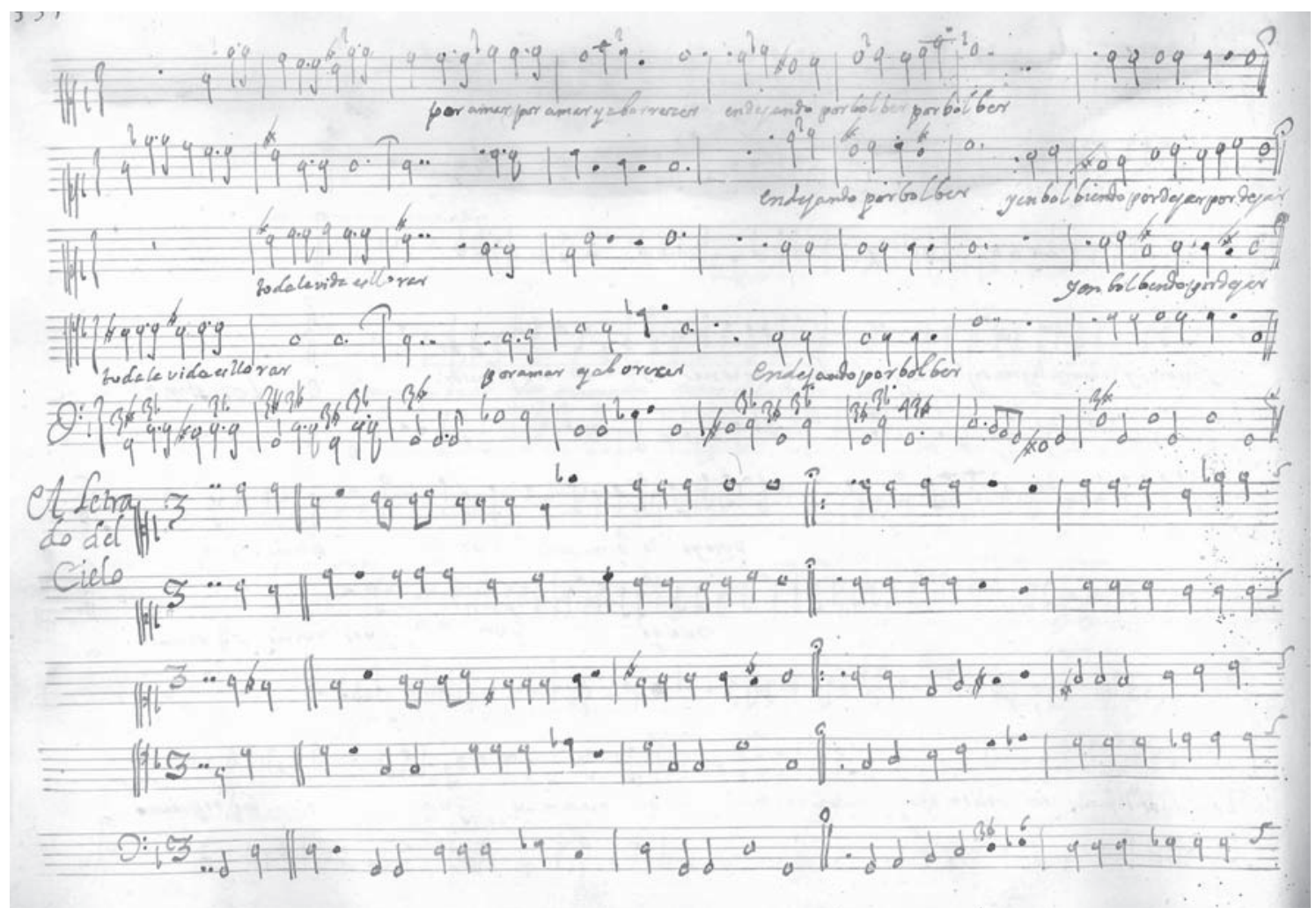

Ejemplo 1. Ms. Novena, fol. 334: “Toda la vida es llorar”. Anónimo. 
Toda la vida es Ilorar

Anónimo, Ms. Novena, fol. 334 Transcripción: Luis Robledo

[Tiple I]
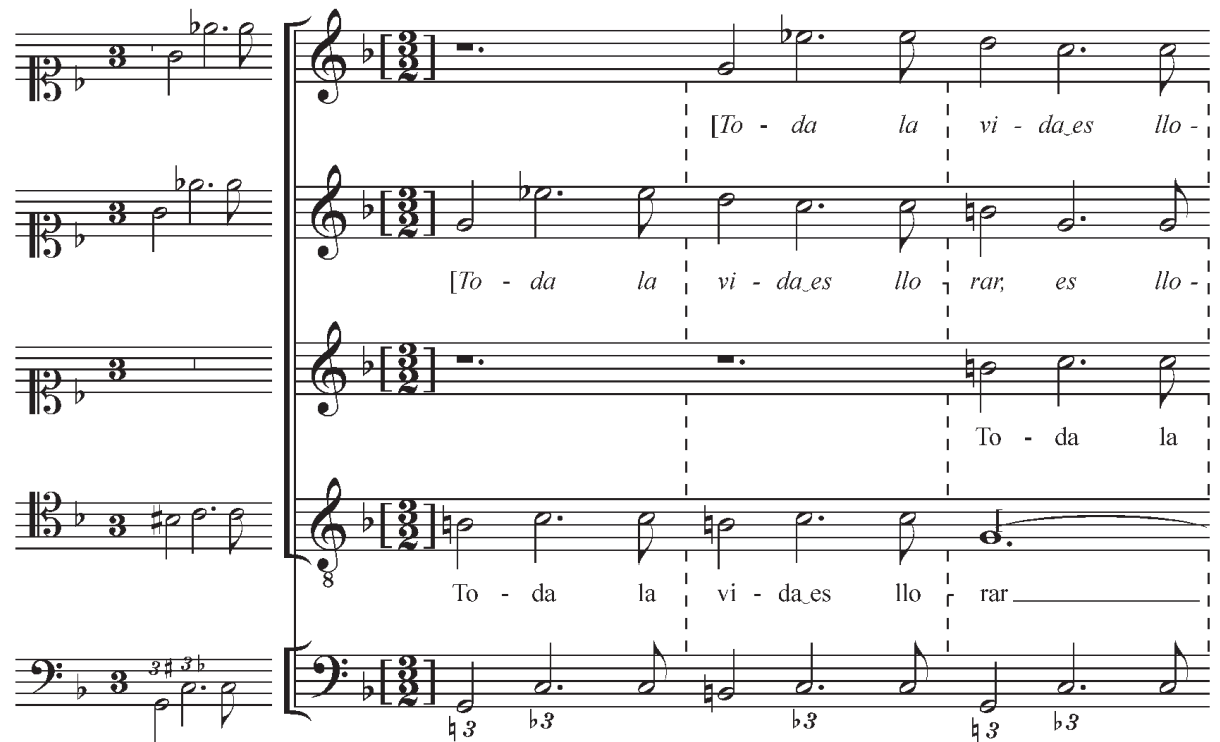

[Acompañamiento]

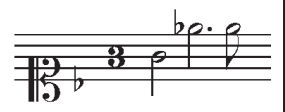

[Tiple III]

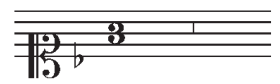

[Tenor]
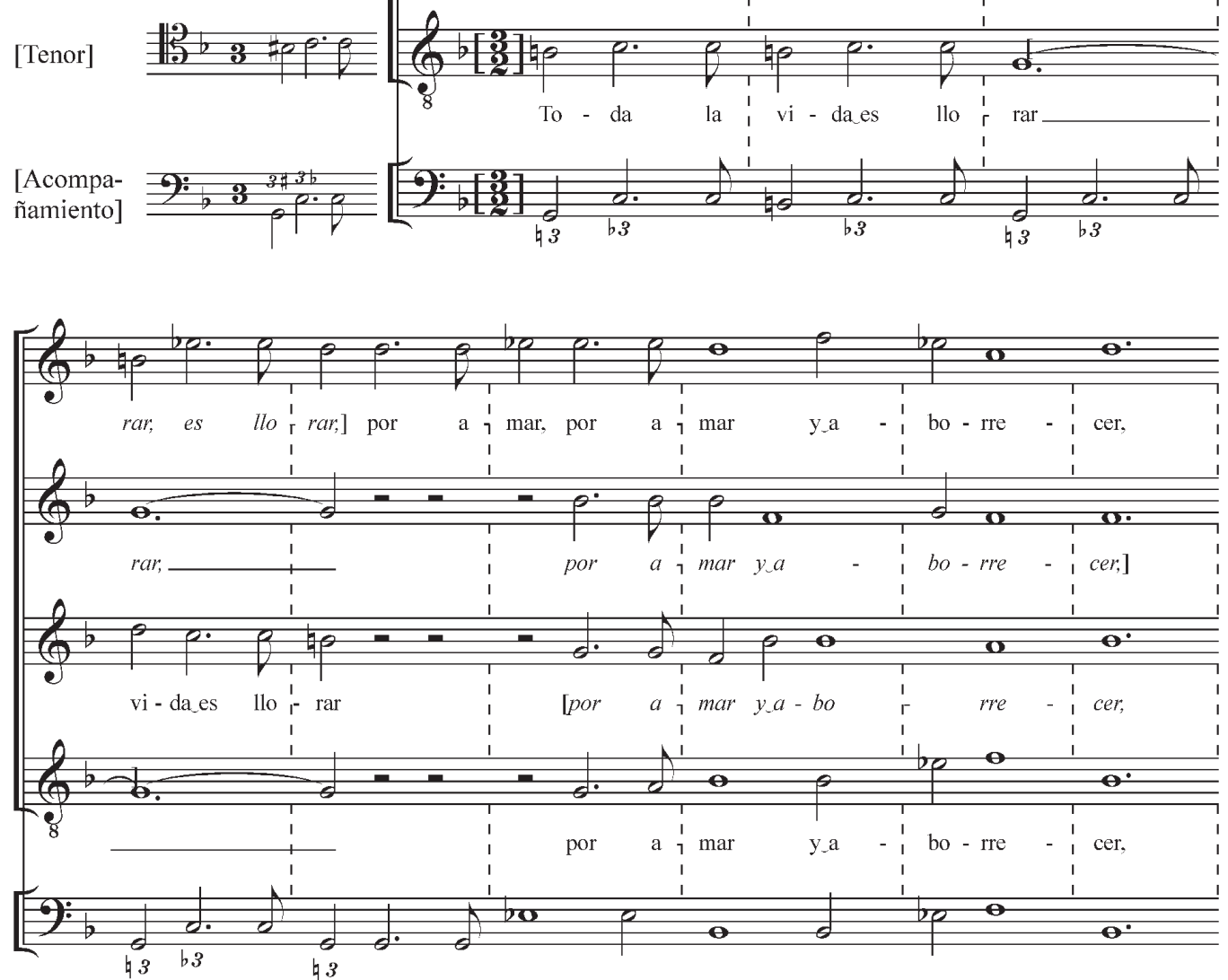

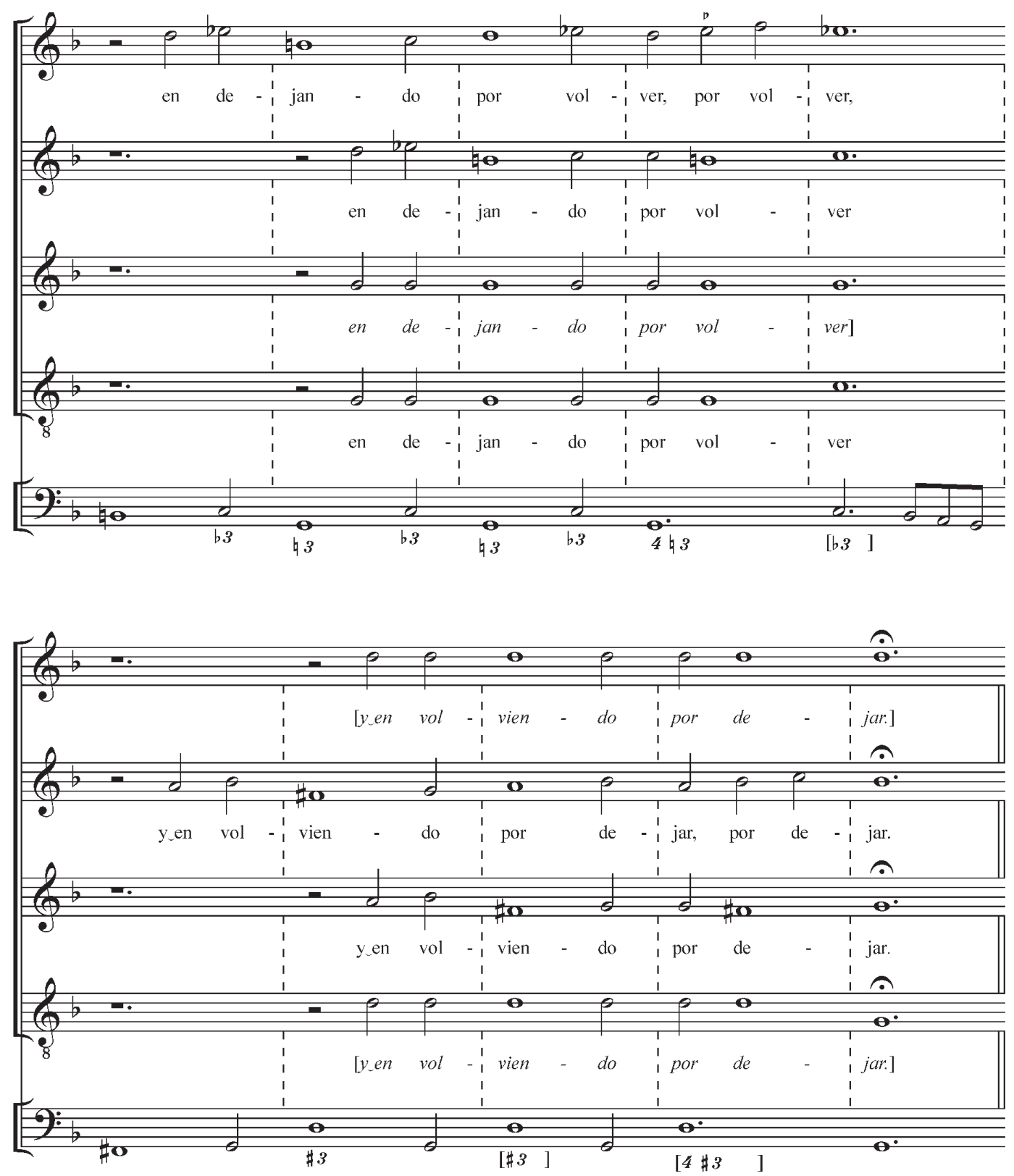

Ejemplo 2. Ms. Novena, fol. 334: “Toda la vida es llorar”. Anónimo. Tr. Luis Robledo.

Recibido: 29/06/2009

Aceptado: 17/03/2010 